\title{
人体帯電電位を決定づける靴の電気定数の特性測定
}

\author{
正員藤 原修 (名古屋工大) \\ 学生員 竹下裕 章 (名古屋工大)
}

\section{Measurement of Electrical Properties of Shoes Determining Charged Human Body Potential}

Osamu Fujiwara, Member, Hiroaki Takeshita, Student Member (Nagoya Institute of Technology)

Serious failure of the latest high-tec equipment occurs easily due to electrostatic discharge (ESD), which is known to be often caused by electriffcation phenomena of human-body walking on the floor. On the one hand, it has widely been accepted that the ESD is difficult to happen in the high humidity environment, on the other hand this mechanism is not well understood. In order to study the electrical factors that govern the walking electrification in the high humidity environment, we measured electrical parameters (capacitance: $C_{S}$, resistance: $R_{S}$ ) of the commercially available shoes having synthetic rubber soles that determine the potential of the human body walking on a metal plate. As a result, we found that an equation of " $C_{S}^{\varepsilon} R_{S}=$ constant" holds regardless of the humidity and the power number $\xi$ for the rubber sole shoes falls in the renge from 3 to 5 , which can theoretically be explained from moisture absorption properties of the dielectric material.

キーワード: 静電気放電, 人体帯電電位, 靴, 電気定数, 吸湿特性

\section{1、まえがき}

情報機器の高性能化と爆発的な普及に伴い, 電磁ノイズ による機器の詿動作問題がクローズアップされている(1)。 ことに, 静電気放電 (Electrostatic discharge; ESD) で 生ずる過渡的な電磁雑音怯，八イテク機器に深刻な電磁障 害を引き起こし，高度エレクトロニクス化をはばむ脅威と なっている(2)(6)。この ESD の主要因の一つに人体の帯電 現象が知られている。例えば，オフィスビル内での高分子 床材上の歩行や椅子からの立上りなどで人体が高電位に帯 電し, 情報機器に触れることでESDが発生し, これによ って機器障害が引き起こされる。しかしながら，ESD 源 となる肝心の人体電位の発生や減衰機構についてはまだ不 明の部分が多い。著者らはさきに，床材上の人体電位減衰 過程を入体容量や靴・床材料の電気定数との関係において 解明した(7)。更に，低抵抗床材として使用される金属板上 での人体電位の上昇過程や減衰過程扔よび連続歩行の带電 機構についても明らかにした ${ }^{(8)(9)}$ 。一方, 高湿度の環境下 では歩行動作における人体電位は一般には上昇しにくいこ とが認識されているが，それを決定づける要因は明確でな w。

本論文は，金属板上で步行動作時の人体带電電位を左右 する靴の電気定数（容量： $C_{s}$, 抵抗： $R_{s}$ ）を測定し, 湿
度には無関係に「 $C_{s}^{\frac{\hbar}{6}} R_{s}=$ 一定」が成り立つこと，合成ゴ 么底靴では $\xi=3 \sim 5$ であることを示す。

\section{2. 測 定 法}

靴の電気定数の測定法(8)を図 1 に示す。金属板上で男 子の被験者（23歳，身長：177 cm, 体重：65 kg）を図 1(a)k示すように高抵抗 $(10 \mathrm{M} \Omega)$ とリードスイッチを 介した高電压源で $V_{B O}(=500 \mathrm{~V})$ に充電する。次に,リー ドスイッチで時刻 $t=0$ において電源をオフしたときの人 体電位 $v_{B}(t)$ を, 図 $1(\mathrm{~b})$ の左図に示す䋸衝増幅器（入力 抵抗: $R_{i}=10.26 \mathrm{M} \Omega$, 入力容量: $C_{i}=19.6 \mathrm{pF}$, 以下は 単に増幅器と呼ぶ）または同右図の回転セク夕型電位計 (入力容量は $C_{m}=18.0 \mathrm{pF}$ で測定法は後述, 以下は電位計 と呼ぶ）で測定すれば，前者の電位減衰特性から靴の容 量, 後者のそれから靴の抵抗を求めることができる。な お, 前者の增偪器は正しくは高電位の人体電位を $\mathrm{A} / \mathrm{D} コ$ ンバータへ導くための電圧減衰器であるが,ここでは増幅 器と呼ふことにする。また, 增幅器の入力抵抗 $R_{i}$ と入力 容量 $C_{i}$ とはインピーダンス計 (LCRメータ, 測定周波 数： $120 \mathrm{~Hz}$, 测定確度： $\pm 0.5 \%$ ) で実測した。

いま, 被験者の人体容量を $C_{B}(=120.6 \mathrm{pF}$, 測定法は後 述), 鞉容量と靴抵抗をそれぞれ $C_{S}, R_{S}$ とすれば, 上述 した各測定法の等価回路は図 1(b)に対応して (c)図のよ 
(a)

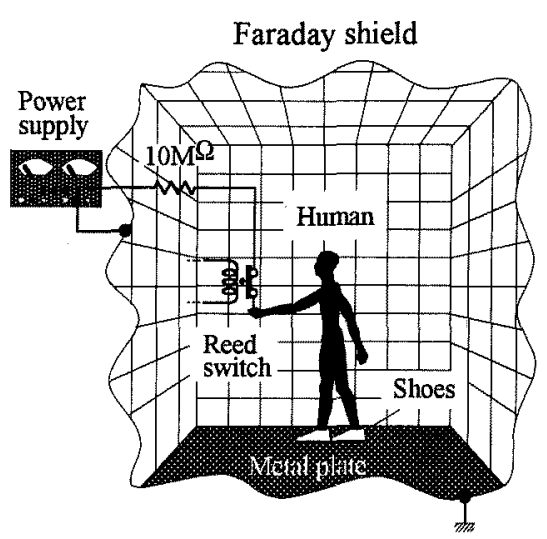

Faraday shield

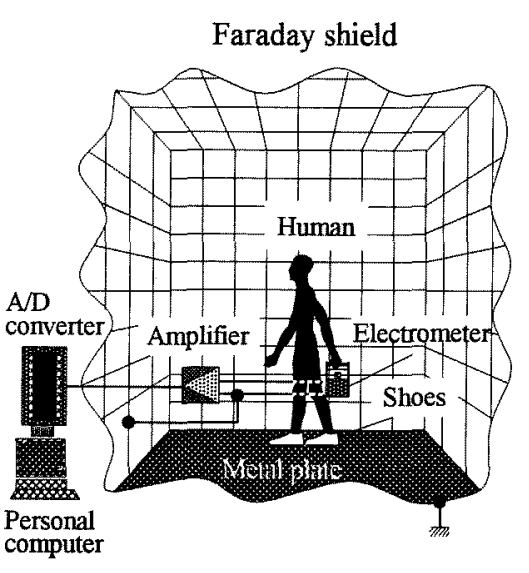

(b)

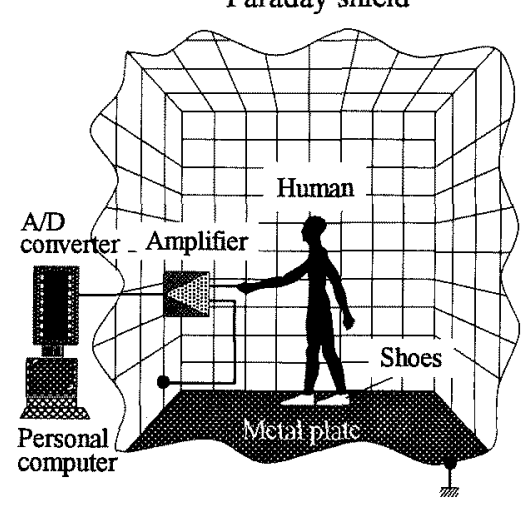

Power Amplifier
supply
shoe $\underset{\text { body }}{\text { Human }} \underset{\text { shoee }}{\text { Right }}$

(c)
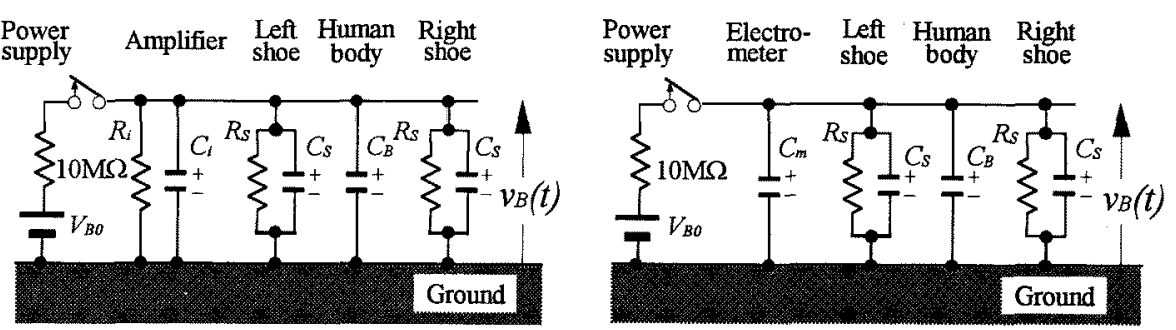

図 1 測定法 (a)，（b) と等価回路 (c)

Fig. 1. (a), (b) Measurement methods and (c) equivalent circuits.

うに表される。ただし，靴の電気定数は左右とも等しいと

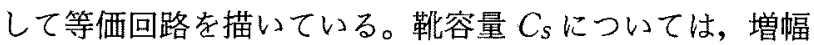
器の入力抵抗 $R_{i}$ が靴抵抗 $R_{s}$ に比べて十分小さいものと すれば，(c)図から人体電位は

$$
\frac{v_{B}(t)}{V_{B 0}} \simeq \exp \left[-\frac{t}{\left(C_{i}+C_{B}+2 C_{S}\right) R_{i}}\right]
$$

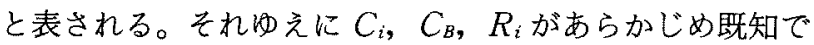
あるならば，この減衰特性から $C_{S}$ が求められる。鞉抵抗 $R_{s}$ については， $C_{S}$ を得れば $(\mathrm{c})$ 図右図から人体電位が

$$
\frac{v_{B}(t)}{V_{B O}}=\exp \left[-\frac{t}{\left(C_{m}+C_{B}+2 C_{S}\right) R_{S} / 2}\right]
$$

となるので， $C_{m}, C_{B}$ があらかじめ既知であるならば，こ れから $R_{S}$ が求められる。ただし，人体容量 $C_{B}(=120.6$ $\mathrm{pF})$ と電位計の入力容量 $C_{m}(=18.0 \mathrm{pF})$ は文献 $(8)$ を参 考にして，次のように求めた。人体容量の測定に際して は，金属板上で靴と同形状の発泡スチロール（厚さ：2 $\mathrm{cm}$, 面積: $\left.26.7 \mathrm{~cm}^{2}\right)$ の上に被験者を裸足で直立させる。 発泡スチロールは空気とほほ同じ誘電率をもつので，この 場合の被験者は金属板上で靴の厚さだけ空中に浮いた格好 となる。それゅえに，この状況にある被験者の電位を増幅 器で測定し, 同减衰特性から $C_{B}$ を求めた。電位計の入力 容量は， $C_{B}$ を得た後に電位計を片手に持った被験者の增 幅器を介した電位減衰特性から求めた。

表 1 は測定に用いた靴と寸法諸元を示す。靴牥市販の合 成ゴム底のものを 8 種類用意しこえららの電気定数の測定 を 20 の異なる湿度環境下（相対湿度：61.4〜 86.9\%, 温 度：23.7〜28.4ㅇ）で行った。ただし，これらの湿度環境 は人工的に制御して実現したわけではない。晴天や雨天の 時期を見計らって数多くの実験を行い，湿度の大きく異な る測定環境下での実測データを集めた。実験ごとに人体容 量 $C_{B}$, 増幅器の入力抵抗 $R_{i}$ と入力容量 $C_{i}$, 電位計の入 力容量 $C_{m}$ を測定したが，これらは湿度の影響をほとんど 
表 1 測定に用いた鞉とその寸法諸元

Table 1. Shoes used for measurement and their dimension.

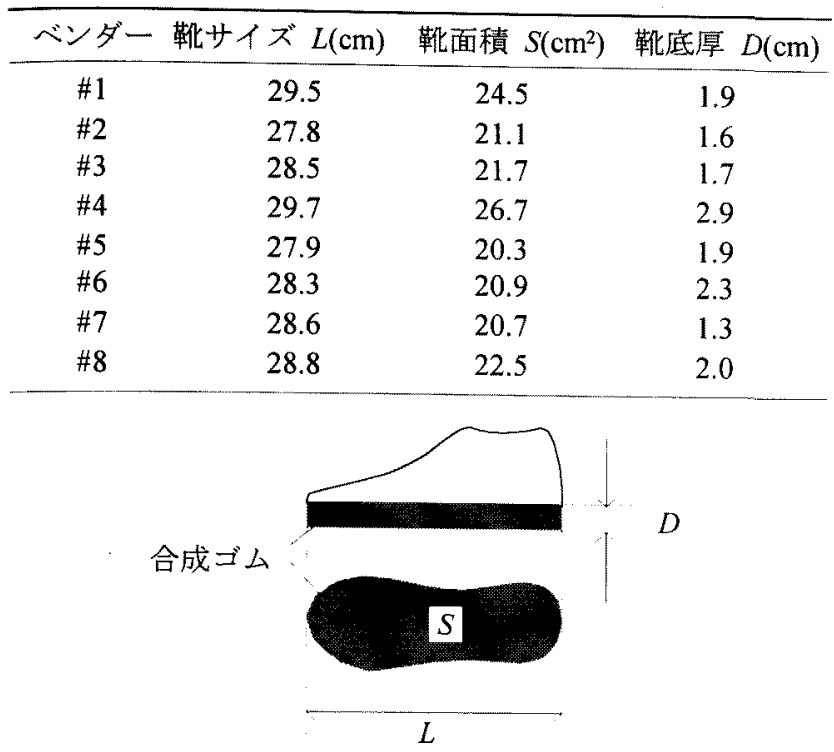

受けなかった。また，増幅器による測定においては $\mathrm{A} / \mathrm{D}$ コンバータのサンプリング周波数を $100 \mathrm{kHz}$, 測定時間 を $0.1 \mathrm{~s} と し$, 電位計による測定ではサンプリング周波数 は $2.5 \mathrm{kHz}$, 測定時間は $250 \mathrm{~s}$ (約 4 分) とした。また, 電位測定に際しては，金属板をグラウンドとし，測定機器 のアースをこれに接続した。

\section{3. 実験結果と考察}

図 2 は，20の異なる湿度環境下において靴苏 1 を履いた 被験者の電位隇衰特性を測定した例を示す。(a)図は靴容 量を求めるために增幅器を介して測定した電位減衰特性で あり，(b)図は靴抵抗を求めるための電位計による測定例 である。ただし，縦軸は初期電位 $V_{B O}$ で規格化した人体 電位を対数目盛で表している。図から，同じ靴でも湿度の 上昇とともに電位減衰の時定数が (a)図では延び, (b)図 では大幅に短くなっていることがわかる。このことは, 湿 度が上昇すると靴容量 $C_{s}$ は増加し, 靴抵抗 $R_{s}$ は大きく 減少することを意味する。また，いずれの測定值も $0.1 \leq$ $v_{B}(t) / V_{B O} \leq 1$ では括扔むね直線上に乗つているので, (1)，(2)式を最小 2 乗法で測定值に当てはめることによ って種々の湿度環境下に抬ける $C_{S}$ と $R_{S}$ が推定できるこ とがわかる。

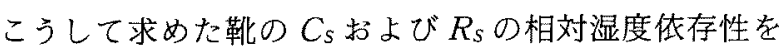
図3に示す。図から, 靴の容量值と抵抗值はそれぞれ $7 \sim 276 \mathrm{pF}, 4 \times 10^{(8 \sim 12)} \Omega$ の範囲にあること, どの靴におい ても 60〜90\%の湿度変化に対して靴容量は確かに増加し ているが，その程度はたかだか 2 倍であること，しかしな がら靴抵抗は大きく滅少し，その程度は $1 / 10$ 倍であり, 湿度に対して容量值よりも抵抗值のほうが大きく変化して いること, などがわかる。図 4 は, 20 の買なる湿度環境 (a)

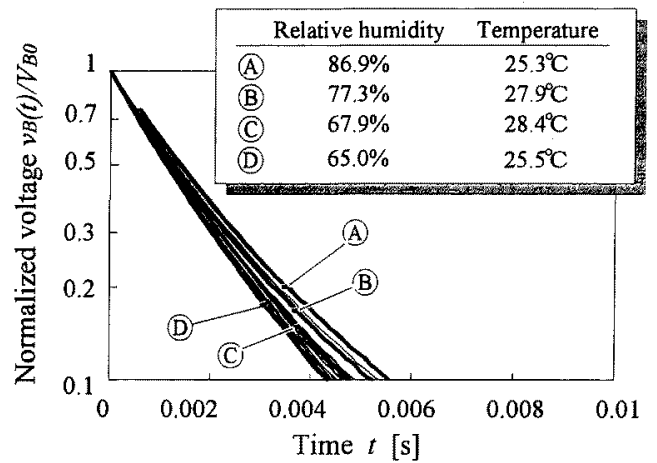

(b)

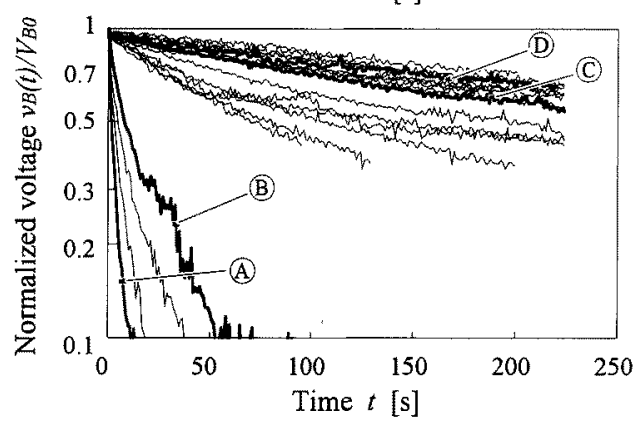

（a）靴容量を求めるための人体電位隇衰特性

（b）靴抵抗を求めるための人体䉓位隇衰特性

図 2 人体電位減衰特性の測定例

Fig. 2. Measured human-body potentials.

(a)

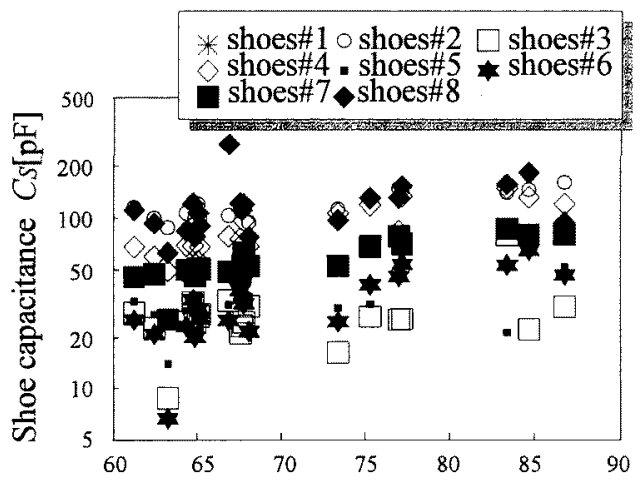

(b)

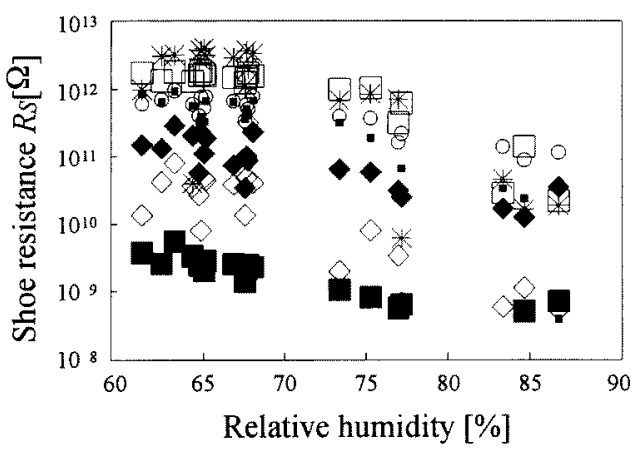

図 3 鞉容量 (a) と鞉抵抗 (b) の相対湿度依存性 Fig. 3. Dependence of (a) shoe capacitance and (b) shoe resistance on relative humidity.

下で測定した靴抵抗 $R_{S}$ と鞉容量 $C_{S}$ との定量関係を両対 数グラフで示す。図中の各直線は最小 2 乗法で実測データ に当てはめた $\left\lceil C_{s}{ }^{6} R_{s}=\right.$ 一定」を表す直線であり, 各靴に 
(a)

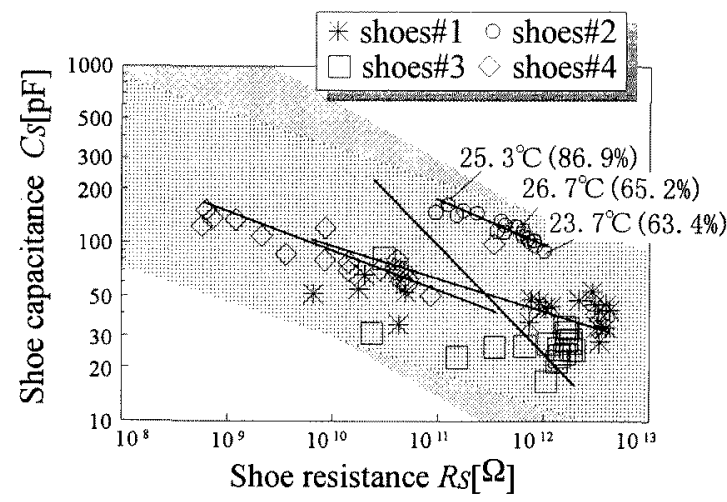

(b)

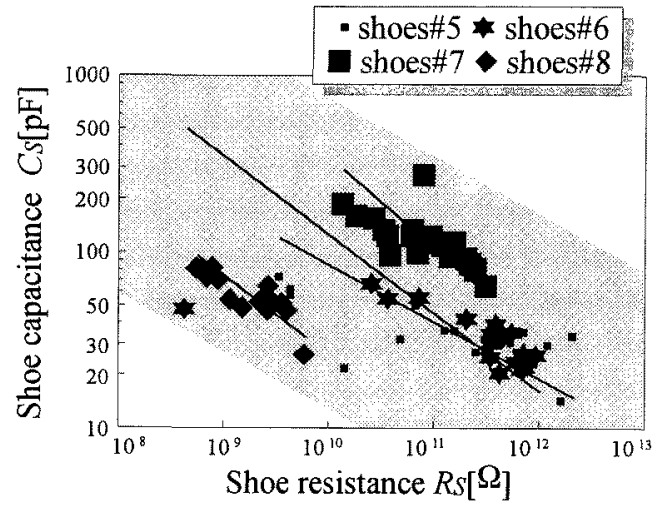

図 4 靴抵抗と靴容量との定量関係

Fig. 4. Quantitative relationship between shoe resistance and shoe capacitance.

表 2 実測デー夕に当てはめた $\left\lceil C_{s}{ }^{E} R_{s}=\right.$ 一定」 のべき数 $\xi$ と相関係数 $\gamma$

Table 2. Power number $\xi$ and correlation coefficient $\gamma$ of " $C_{s}{ }^{\epsilon} R_{s}=$ constant" that explains the measured data.

\begin{tabular}{ccc}
\hline ベンダー & ベき数 $\xi$ & 相関係数 $\gamma$ \\
\hline$\# 1$ & 5.4 & -0.53 \\
$\# 2$ & 3.4 & -0.92 \\
$\# 3$ & 1.7 & -0.48 \\
$\# 4$ & 4.5 & -0.79 \\
$\# 5$ & 3.1 & -0.63 \\
$\# 6$ & 2.7 & -0.89 \\
$\# 7$ & 2.8 & -0.87 \\
$\# 8$ & 3.1 & -0.88 \\
\hline
\end{tabular}

対するべき数 $\xi$ と相関係数 $\gamma$ は表 2 にまとめて示す。表 2 によると, shoes\#1, Shoes\#3, shoes\# 5 を除く他の 靴の相関係数はいずれもほぼ $80 \%$ を超えていること，こ の場合のべき数 $\xi$ 值は 2.7 4.5 の範囲にあること，など が知られる。なお，(a)図の粗い網掛け部分の傾きは $\left\lceil C_{S}{ }^{5} R_{s}\right.$ 二一定」を表し，細かい網掛けと（b)図の網掛け 部分の傾きは「 $C_{S}{ }^{3} R_{S}=$ 一定」を表している。図 4 から， 種々の湿度環境に扔いて, ほとんどの靴の電気定数が $\left\lceil C_{S}{ }^{(3-5)} R_{S}=\right.$ 一定」の直線に沿ってお扔上そ並んでいるこ とが読み取れる。但し，この関係式の右辺は各靴（したが って，製造業者）ごとに異なった値を示している。

\section{表 3 靴底用合成ゴムの比誘電率と体積抵抗率} 抒よび $\beta / \alpha$

Table 3 Relative permittvity, volume resistivity and $\beta / \alpha$ of synthetic rubber material used for shoe sole.

\begin{tabular}{|c|c|c|c|}
\hline 材貿 & 比幖電率 $\varepsilon_{\mathrm{s}}$ & 体積抵抗率 $\rho_{\mathrm{s}}\left[\Omega_{\mathrm{m}}\right]$ & $\beta / \alpha$ \\
\hline ポリイソブレン & $3 \sim 4$ & 1013 & $6.3 \sim 6.9$ \\
\hline クロロプレンゴム & $6 \sim 8$ & $10^{8} \sim 10$ & $3.5 \sim 6.0$ \\
\hline ブタジエンースチレン共重合ゴム & $3 \sim 7$ & $10^{12 \sim 13}$ & $5.6 \sim 8.5$ \\
\hline ブチルゴム & $3 \sim 4$ & $10 \div 3 \sim 14$ & $6.3 \sim 7.7$ \\
\hline エチレンープロピレンゴム & $3 \sim 4$ & $10^{13 \sim 14}$ & $6.3 \sim 7.7$ \\
\hline
\end{tabular}

この結果は次のような機構で生じたものと推察する。水 の比誘電率 $(81)$ が合成ゴムの比誘電率（3〜8）に比べて十 分大きく，水の抵抗率 $\left(10^{4} \Omega \cdot \mathrm{m}\right)$ が合成ゴムの抵抗率 $\left(10^{8-14} \Omega \cdot \mathrm{m}\right)$ に比べて極めて小さいことを考慮し，本論 文では湿度変化に対する靴の電気定数が靴底材質の吸湿特 性に支配されるものと仮定する。なお，一般に合成ゴムの ような絶縁物の抵抗值は体積抵抗と表面抵抗に支配される が，靴のような構造に対しては足裹接触面と靴底の金属板 接触面との間の抵抗值に表面抵抗がどれ恬ど寄与するかは 不明であるので，ここでは体積抵抗だけを考察の対象とす る。また, 合成ゴムの比誘電率や抵抗率の温度依存性も存 在するが, 測定環境の温度変化に対しては, 吸湿による電 気定数值のほうが遥かに大きく変わるので，本論文では温 度変化による影響は考えない。さて，一般に合成ゴムを含 む誘電体の含水率は周囲環境の湿度に応じて変化するの で,これを $m(0 \leq m \leq 1)$ とし, そのときの誘電体の容量 值を $C_{S}(m)$, 抵抗值を $R_{S}(m)$ とすれば, 両者の湿度依存 性に関しては

$$
\begin{aligned}
& C_{S}(m)=C_{s}(0) \exp (\alpha m) \cdots \\
& R_{s}(m)=R_{s}(0) \exp (-\beta m)
\end{aligned}
$$

という実験式 ${ }^{(10)}$ が知られている[但し，(4)式は含水率 $m$ が数\%以内の範囲で成り立つとされるが，この範囲を 大きく超えた含水率 $m$ に対して適用できる抵抗值の実験 式はまだ見いだされていない)。ここに， $\alpha ， \beta$ 注材質や形 状によって決まる定数である。(3)，(4)式から $m$ を消 去すれば, $C_{S}(m)$ と $R_{S}(m)$ との間には

$$
C_{S}(m)^{\beta / \alpha} R_{S}(m)=C_{S}(0)^{\beta / \alpha} R_{S}(0)
$$

という関係式が成り立つ。この式の左辺は誘電体固有の定 数であり, 湿度には無関係である。靴容量のべき数 $\beta / \alpha$ に ついては，次のように考える。(4) 式が $m=0 \sim 1$ の範囲 で成り立つものと仮定し， $m=1$ (含水率：100\%)のとき は鞉底材質の電気定数が水の電気定数と等しくなるものと する。そのとき，(3)，(4)式より

$$
\begin{aligned}
& C_{S}(1)=C_{S}(0) \exp (\alpha)=\frac{\varepsilon_{w}}{\varepsilon_{S}} C_{S}(0) \\
& R_{S}(1)=R_{S}(0) \exp (-\beta)=\frac{\rho_{w}}{\rho_{S}} R_{S}(0)
\end{aligned}
$$

となる。ここで, $\varepsilon_{s}, \rho_{s}$ は $m=0$ (含水率：0\%) とした 誘電体そのものの比誘電率および体積抵抗率であり, 
$\varepsilon_{w}(=81), \rho_{w}=\left(=10^{4} \Omega \cdot \mathrm{m}\right)$ は水の比誘電率および体積 抵抗率である。（6)，（7)式から，(5)式における $C_{s}(m) の \beta / \alpha$ は

$$
\frac{\beta}{\alpha}=-\frac{\ln \left(\rho_{w} / \rho_{S}\right)}{\ln \left(\varepsilon_{w} / \varepsilon_{s}\right)}
$$

で与えられる。実験に用いた靴底材質は特定できなかった ので, 文献(11)にある各種合成ゴムの比誘電率および体積 抵抗率から, $\beta / \alpha$ の数值を求めた。この結果を表 3 に示 す。表から, 合成ゴム材質の容量 $C_{S}$ と抵抗 $R_{s}$ との間に は, どの湿度環境下でも「 $C_{S}{ }^{3.5 ~ 8.5} R_{S}=$ 一定」という関係 式が成り立つことがわかる。この結果は表 2 のべき数值の 妥当性を裏付けるものと考える。

\section{4.むすび}

一般に高湿度環境下においては人体は帯電しにくいとさ れるが，これを決定づける要因は明確でない。本論文で は，金属板上での歩行人体電位を支配する靴容量 $C_{S}$ と靴 抵抗 $R_{S}$ とを測定し，湿度の異なる測定噮境では靴底の材 質や形状によらず「 $C_{S}{ }^{c} R_{S}=$ 一定」をほぼ満たすこと，合 成ゴム底靴では $\xi=3 \sim 5$ であること，などを見いだした。 これらの関係式の成立根拠は靴底材質の吸湿特性から理論 的に説明できた。なお，本論文で得た $\left\lceil C_{S}{ }^{\varepsilon} R_{S}=\right.$ 一定」の 関係式は, 湿度環境に対する人体の帯電特性を靴の電気定 数の変化として取り扱うことを可能とするものである。

今後の課題は, 歩行人体や移動機材の帯電電位を左右す る床材質において, 吸湿特性を考慮した電気定数值の間で 成り立つ定量関係を明らかにすることである。

(平成 9 年 4 月 3 日受付, 同 9 年 8 月 7 日再受付)

$$
\text { 文献 }
$$

（1）例えば, 伊藤健一：「ノイズ対策技術の動向」, 電学論 C, 115, $512 \sim 516$ (平 7-4)

（2）本田昌實：「金属物体で発生する静電気放電（ESD）の妿威」, 信学誌, 78, 849 850 (平 7-9)

（3）藤原 修：「ESD 現象をとらえるソースモデルと界特性」, 同上， $78,851 \sim 852$ (平 7-9)
(4) W. D. Greason: "Indirect effect of ESD : modeling and measurement", Proc. 11th Int. Zurich Symposium Tech. and Exh. on EMC, 116R1, 613 618 (1995)

(5) T. Honda : "Fundamental aspects of ESD phenomena and its measurement techniques", IEICE Trans. Commun., E79-B, No. 4, 457 461 (1996)

(6) O. Fujiwara: "An Analytical Approach to Model Indirect Effect Caused by Electrostatic Discharge", ibid., E79-B, No. 4, 483 489 (1996)

(7) O. Fujiwara \& H. Endoh: "Computation of potential attenuation process for charged human body using numerical inverse Laplace transform", ibid., E78-B, No. 2, 188 192（1995）

（8）三浦 進・岡崎勝・藤原 修・阿座上孝：「連続歩行に伴う 人体電位の特性測定」, 信学技報, EMCJ 91-18 (平 3-6)

（9）三浦 進・岡崎 勝・藤原 修：「金属板上の足踏みに伴う人 体带電電位の測定 J, 信学論 C, C-II, 156 158 (平 5-4)

(10）高分子学会 高分子と吸湿委員会：材料と水分ハンドブック, pp. 584～631（昭 43）共立出版

（11）電気絶縁材料便筧編集委員会：電気絶縁材料便筧, pp. 354 408 （昭 40）日刊工業新聞社

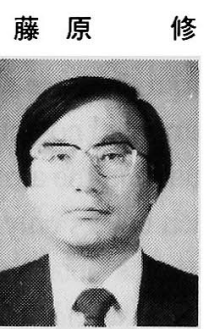

（正員） 1948 年 8 月 11 日生。1971 年名古屋工 業大学工学部電子工学科卒業。1973 年名古屋大 学大学院修士課程修了。同年(株)日立製作所中 央研究所入所。1 976 年同所退職。1980 年名古屋 大学大学院工学研究科博士後期課程修了。名古 屋大学工学部助手, 講師を経て, 1985 年名古屋 工業大学工学部助教授。現在, 同教授。 1991 92 年スイス連邦工科大学客員教授。工学 博士。放電雑音, 生体電磁環境, 環境電磁工学に関する研究に従事。 電子情報通信学会, IEEE 会員。

竹下裕 章 (学生員) 1973 年 1 月 15 日生。1995 年名古屋

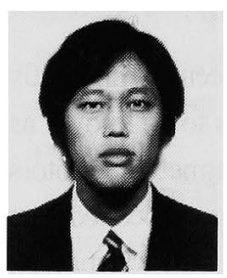
工業大学工学部電気情報工学科卒業。現在, 同 大学大学院博士前期課程在学。(株) リンナイ勤 務。在学中, 環境電磁工学に関する研究に従事。 